\title{
THE IMPLEMENTED ISO SYSTEM AND ITS INFLUENCE ON THE FUNCTIONING OF THE SILESIAN HEALTHCARE ORGANIZATION
}

\author{
Małgorzata NADZIAKIEWICZ \\ Silesian University of Technology, Faculty of Organization and Management, Zabrze; \\ malgorzata.nadziakiewicz@ polsl.pl, ORCID: 0000-0002-0900-4046
}

\begin{abstract}
The article focuses on the advantages of the implementation of a quality management system. It shows the difficulties associated with meeting the expectations of the modern competitive market and the patients' expectations, as well as presents solutions to improve the organization's management systems, in the form of mechanisms that already exist, for example the ISO standard. Implementation of the quality management system has a positive impact on the health care unit, introducing order in managing system and improving quality. Thanks to the implemented quality system, it is possible to provide services at a much higher level, which can be seen in the analysis of satisfaction of patients, managers and medical staff. The article analyzes the importance of a quality system in the health care sector, as well as the quality management according to the newest trends in that sector.
\end{abstract}

Keywords: ISO, quality, healthcare.

\section{Introduction}

In order to meet the expectations of the modern competitive market and the patients, healthcare organization should look for appropriate solutions to improve the organization's management systems. Such mechanisms can be found among the quality standards developed by the International Organization for Standardization, the so-called ISO. The implementation of a quality management system has a positive impact on the functioning of a medical facility introducing order and organization. Thanks to the introduced quality system, it is possible to provide services at a much higher level, which can be seen in the analysis of patient satisfaction, as well as in shaping the right attitude of the staff, along with the increase of their satisfaction with their work. Frequent organizational changes, taking place in the Polish legal system, emphasis on the growing importance of quality and safety of health care, continuous development of medical technology, as well as constantly emerging threats have contributed to 
the fact, that the concept of quality in the Polish health service has gained more importance. It introduces preventive measures, characterized by counteracting the occurrence of risk and threats and their mitigation. The level of quality of services offered to medical facilities is a result of the expectations of the environment. Increasingly, patients demand individual approach, work standardization, stability, predictability, safety of care, as well as faster access to medical services (Trela, 2014). All of these factors affect their satisfaction, and therefore the satisfaction of patients with the quality of services offered.

The quality of healthcare is a complex and interdisciplinary process. It can refer to the improvement in the provision of medical services, as well as the factors important from the point of view of patient safety. Quality can be shaped by:

- the quality of the structure,

- the quality of the process,

- the quality of the result.

It is important to properly monitor and evaluate every stage of the services. Indicators can be positive (the higher the index, the better the quality) or negative (the higher the index, the worse the quality) (Nadziakiewicz, \& Mikolajczyk, 2019).

\section{The importance of quality and its impact on functioning of healthcare units}

In the recent years, it has been noted that ensuring the quality and safety of medical services is also dependent on other factors. Managers of medical entities are increasingly aware that the quality is an important asset of medical units. Medical facilities that are able to survive on the medical services market, as well as acquire new patients, ensure the appropriate level and quality of services rendered.

The World Health Organization has adopted six principles for building and measuring the quality of healthcare:

1. Accessibility, measured by the scale of the reasonable use of care, regardless of the limitations that may be associated with geographical location, money, time, age, language, transport, architecture of the building etc.

2. Equality in the provision of care for the entire population, based on identified needs, regardless of the class of specialists, their cultural, social, racial character or other personal characteristics.

3. Adequacy of the types of health services, packages of services, procedures adapted to the real needs of returning communities, as they are needed, expected or required by the unit. 
4. Inclusive health care takes into account the cultural and religious values of recipients, in order to meet their expectations.

5. Efficiency of managing the available resources, such as: money, buildings, equipment, employees, to ensure that they are used in the most rational way. The basic principle is the highest efficiency at the lowest cost.

6. Efficiency care fulfills its task in terms of benefits and effectiveness (Sułek, 2003).

Health care units should keep up with the growing competition on the market. For medical facilities, the quality management system plays an extremely important role in cooperation with the National Health Fund, which, as a public payer, has been attaching great importance to quality management systems owned by medical entities for some time. The result of this is that the quality criterion is taken into account when assessing contract offers. To a large extent, it was the decision of the President of the National Health Fund that stimulated the interest in quality standards in Polish healthcare system, which resulted not only in the theoretical aspect of this issue, but also forced the implementation and certification of management systems according to the ISO standard. Strengthening the importance of the quality criterion when assessing bids submitted through tender competitions, regarding the conclusion of a contract for the provision of medical services, was announced by the National Health Fund in 2013. This decision contributed to the promotion of medicinal entities with an implemented and certified quality management system, in accordance with ISO (Trela, 2015). The Annex to the Ordinance of the President of the National Health Fund on determining the criteria for the evaluation of bids in the procedure of concluding the contracts for the provision of healthcare services presents the criteria for "external quality assessment", as well as specifies the issue of certificates, which are the basis for obtaining additional points.

The quality management system plays an important role in creating processes that affect the effective functioning of a health care unit. The key issue, enabling the survival of a medical facility in a competitive market, is acquiring new clients and maintaining old ones. It is very important to ensure quality at the appropriate level, which is clearly noticeable at the first contact with the unit. Therefore, taking care of external clients, especially patients, is extremely important. Conducting such activities, which arouse positive feelings, increases the likelihood of a patient's return for given medical services. At the outset, a medical institution that wants to be of high quality should focus on aspects that can distinguish them from their competition. These aspects can be divided into tangible and intangible factors. The material elements include: decor of the registration, waiting rooms, doctor's offices, furniture arrangement, furnishings, decorative elements and wall colors. Considering these elements, it is important to first analyze one's expectations. In this case, it should be taken into account that patients, depending on their age, sex or social status, have different preferences and tastes. In addition to the issue of interior design, the issue of transparency of information boards, schedules, brochures or leaflets is also important, especially in the case of medical facilities that have contracts for the provision of medical services with the National Health Fund, which clearly 
imposes an obligation, specifies the guidelines and the method of sharing information to recipients in accordance with the Regulation of the Minister of Health of May 6, 2008, on the general conditions of contracts for the provision of healthcare services. The waiting room at the healthcare facility should be large enough to accommodate patients awaiting medical consultation. It should not overwhelm with equipment or furniture. Each patient should be properly serviced; therefore, the number of medical registrars should be adjusted to the approximate number of patients. One of the most important issues, affecting the opinion of patients, is the issue of how to manage waiting queues and setting control deadlines. Medical facilities providing private health services can individually regulate the way queues are run, taking into account the number of patients, their age or employment status. In this case, people of retirement age with free time can be registered for the morning hours, so that later hours are reserved for working people. The situation in public medical facilities, unfortunately, looks a bit worse, because they cannot set their own rules, as they have to adapt to the restrictive requirements imposed by the Ministry of Health and the National Health Fund, taking into account "stable cases" and "urgent cases", as well as based only on the medical criteria resulting from legal regulations. A convenient alternative to patients is also the introduction of a system reminding them of an appointment, by e-mail or phone, which also plays an important role in minimizing cases of lateness or failure to appear to the appointment, which causes disorganization of work (Krot, 2015).

\section{Quality as a determinant of good communication with the patient}

Competition in the healthcare sector triggers the need for success among the managers and other personnel of medical facilities, by "outperforming" their competitors. Health care units should nurture relationships with their external clients - patients - because they are the determinant of a well-functioning health care entity. Without them this activity would not make any sense.

The patient's first contact with the facility is extremely important. Therefore, the aforementioned aesthetic experience is important, as well as the way the patient is admitted by the medical registrar. It is recommended for the registration to be located in such a way, that the patient entering the facility would immediately see the waiting registrar. The next important stage in communication with the patient in a therapeutic entity is the doctor's contact with the patient. In practice, it is the relationship with the doctor, their behavior and medical knowledge, that determines patient satisfaction. Other issues only complement this relationship. The physician should be characterized by openness, the ability to listen and understand, thus creating trust in the patient. Due to the wide variety of types of patients, the doctor often has to show patience, commitment and empathy. In contact with the patient, they should also 
demonstrate psychological skills, along with the skillful use of body language. Medical service is treated as a product being sold, then, in this case, the doctor is an element of some kind of "packaging" of this product. Therefore, in addition to the factors mentioned above, that increase the quality of the medical facility, the overall image of the unit's staff, including the manner of conversation, movement, esthetics of clothing, makeup and hairstyle, is also important. The ability to adapt to a given situation is crucial, as is the empathy in a broad sense. The effectiveness of healthcare facilities is a complex concept. It comprises of numerous essential factors. In addition to the implementation of the basic tasks, provided for in applicable normative acts, as well as generally accepted standards, medical entities, in order to meet the expectations of their clients, whose needs and expectations are continuously increasing, must understand the essence of broadly defined quality and understand the ideas of the implemented quality management system, thus overtaking their competition by offering an interesting and comfortable offer of their services.

\section{The impact of the quality management on the functioning of the health care unit in the opinion of managers}

Interview with the managers of five Silesian health care units were conducted in order to examine how the implementation of a quality management system influenced the functioning of their hospitals. Proceeding from the thesis that managers decide on and accept the changes made in health care units during the implementation of ISO, are responsible for the creation of the organizational culture managed by quality, as well as take part in the process of introducing organizational changes (ISO implementation process leads to organizational changes), the selection of respondents was deliberate. The research was carried out a year after the implementation of a quality management system in five non-public health care units in Upper Silesia. The respondents were people who had a direct impact on the quality management system implementation processes. Interviews were conducted at the same time frame, i.e. a month or a year after the implementation of the ISO standard. The respondents were asked questions regarding five basic issues regarding the factors motivating managers to make a decision about implementing a quality management system:

1. What were the motivating factors which made them decide about the implementation of the ISO?

2. Has the implemented system changed the work process for the better?

3. Are they satisfied with the implementation of the ISO?

4. What additional changes should be made to improve the quality of work in the managed facility?

5. Does the management decide on the acceptance of changes made in health care units? 
The interviews consisted of open questions and lasted no more than 20 minutes.

To the first question, the respondents gave the following answers. They noticed the same motivating factors, which influenced the decision about implementing the quality management system. Their aim was to:

1. Increase the prestige of the facility,

2. Improve the quality of work,

3. Adapt to applicable laws,

4. Improve work organization,

5. Improve document flow, which is necessary for the archiving process.

In the second question, all respondents agreed that:

1. The quality management system implementation had changed the work process for the better.

2. In addition, it was found that employees began to comply with the applicable procedures, facilitating the functioning of the quality management system.

3. The implemented quality management system contributed to noticing the differences and deficiencies in the facility's operations.

4. Centralized supply and increased flexibility help in analyzing the medical market.

To the third question, the respondents answered that:

1. They were satisfied with the implementation of the quality management system in their facilities. The system obliged the staff to work better. An improvement in the documentation processes was also noticed.

To the fourth question, about additional changes that should be made to improve the quality of work in the managed facilities, the respondents gave the following answers:

1. Procedures should be improved, while improving the quality of services.

2. It is also important to satisfy patient's needs.

It can be stated, that the respondents see the need for continuous changes, in order to improve the quality of work in the organization. They pay attention to the reception of the facility by an external client - the patient.

To the fifth question, the respondents unanimously answered:

1. That managers are the drive of all changes,

2. The cooperation of the whole team at the health care unit is necessary.

Quality in health care is not only necessary for economic reasons, it allows to compete with other organizations, but also organizes the unit, improves procedures, reduces costs and improves the patients' satisfaction with services offered. Quality can be treated as a tool for improving all areas of human activity. Quality is the fulfillment of requirements and expectations. Also the cost-effectiveness analysis presents high results, providing evaluation needed to make business decisions, but the quality assessment system helps to supervise the whole healthcare organization (Weinstein, Siegel Gold, 2007). 


\section{Conclusion}

In the recent years, it has been noted that ensuring the quality of medical services is necessary. Managers of medical entities have realized that quality is an important asset of medical units. Thanks to the implementation of a quality management system healthcare units are able to survive on the medical market, as well as acquire new patients and provide appropriate level and quality of services. Healthcare units have to keep up with the growing competition on the market. The implemented quality system allows for better adaptation to the market requirements, making the health care unit more flexible and open to new requirements related to contracting by the National Health Fund. The quality assessment system is a tool to supervise organizational and technical factors within the organization. A certification system (ISO) is a proof of order in all areas of the organization. However, this system should be a matter of constant attention, because the quality system is a living organism, that must be regularly supervised and improved. The phenomenon of our time is the noticeable increase in the importance of the quality function. Quality is becoming the most important tool in market competition. Constant monitoring and evaluation at every stage of medical services are the most crucial (Wu, \& Lee, 2006).

\section{References}

1. Krot, K.(2015). Jakość i marketing ustug medycznych. Warsaw: Wolters Kluwer Polska Sp. z o.o., 11-13.

2. Nadziakiewicz, M., Mikolajczyk, A. (2019). The quality and safety of health care services. Manage. Syst. Prod. Eng., 27, 2, 100-104, bibliogr. item 17.

3. National Institute for Health and Clinical Excellence Costing tools. http://www.nice.org.uk/page.aspx?o= costingtools, 9 February 2019.

4. Rozporządzenie Ministra Zdrowia z dnia 21 grudnia 2006 r. w sprawie rodzajów i zakresu dokumentacji medycznej w zakładach opieki zdrowotnej oraz sposobu jej przetwarzania (Dz.U. Nr 247, poz. 1819 z późn. zm.).

5. Rozporządzenie Ministra Zdrowia z dnia 26 września 2005 r. W sprawie kryteriów medycznych, jakimi powinni kierować się świadczeniodawcy, umieszczając świadczeniobiorców na listach oczekujących na udzielenie świadczenia opieki zdrowotnej (Dz.U. 2005, nr 200, poz. 1661).

6. Stachak, S. (1997). Wstęp do metodologii nauk ekonomicznych. Warsaw: Książka i Wiedza, 354.

7. Sułek, A. (2003). Zdrowie i zarzadzanie, V, 6, 26. 
8. Trela, A. (2014). Rośnie rola norm jakościowych. Zarządzanie placówka medyczna, Numer specjalny 13 luty-kwiecień. Warsaw: Wydawnictwo Wiedza i Praktyka, 6.

9. Trela, A. (2015). NFZ bardziej doceni jakość. Zarzadzanie placówka medyczna, 1(62). Warsaw: Wydawnictwo Wiedza i Praktyka, 33.

10. Tuckman, A. (1994). The Yellow Trick Road. Total Quality Management and the Restructuring of Organization Studies, 5, 730.

11. Verboom, B., Montgomery, P., Bennett S. (2016). What factors affect evidence-informed policymaking in public health? Protocol for a systematic review of qualitative evidence using thematic synthesis. Syst. Rev., 5, 61.

12. Weinstein, M.C., Siegel J.E., Gold, M.R. (2007). The Panel on Cost Effectiveness in Health and Medicine et al Recommendations of the Panel on Cost-Effectiveness in Health and Medicine. JAMA.

13. Wu, S.H., Lee, J. (2006). A comparison Study of Nursing Care Quality in Different working Status Nursing Staffs: an example of one Local Hospital. J. Nurs. Re., 181-188.

14. Zarządzenie Nr 3/2014/DSOZ Prezesa Narodowego Funduszu Zdrowia z dnia 23 stycznia 2014 r. w sprawie określenia kryteriów oceny ofert w postępowaniu w sprawie zawarcia umowy o udzielanie świadczeń opieki zdrowotnej. 